\title{
Exploring market orientation, product innovation and competitive advantage to enhance the performance of SMEs under uncertain events
}

\author{
Siti Fatonah ${ }^{\mathrm{a}^{*}}$ and Aris Tri Haryanto
}

\begin{tabular}{l}
${ }^{a}$ School of Economics AUB Surakarta. Ind \\
\hline A B S T R A C T \\
\hline Article history: \\
Received January 18, 2021 \\
Received in revised format May \\
20,2021 \\
Accepted July 222021 \\
Available online \\
September 222021 \\
\hline Keywords: \\
Market orientation \\
Product innovation \\
Competitive advantage \\
Marketing performance \\
Market uncertainty
\end{tabular}

\section{Introduction}

Innovation and achievement of corporate competitive advantage play a strategic role in improving business performance in a rapid environmental change (Simpson, 2004). Innovation also plays a strategic role for a company in building its competitive advantage (Hsu, 2012; Priagung Hutomo \& Pudjiarti, 2021). Various efforts need to be performed by business players in improving its marketing activities, that is also an important part in creating strategy through new product development, focus on marketing activities, thus it is able to create competitive advantage for survival in the market (Munck et al., 2020; Lertpachin et al., 2013). The study conducted by Gomes et al. (2009) explains competitive advantage and business operational activities in an increasingly complex environment and conditions that need business strategy that is able to quickly respond to competitors' movement. In a dynamic, globally competitive, technology-based environment, a company's orientation only to strategy may be insufficient. Company needs to respond to and collaborate with business partners for the organization's survival. Bharadwaj et al. (1993) explain the purpose of competition strategy is to achieve continuous competitive advantage and, thus, improve business performance. In addition, company strategy is directed more to improving the company's long-term operational performance (Yu et al., 2018). Long-term performance may be reached through orientation to customers, competitors and cross-functional coordination in the company, thus competitive advantage may be achieved (Huhtala et al., 2013). Besides innovation with impact on business performance, the role of collaboration and market orientation in company networking also contributes to performance. Kropp et al. (2006) find that innovation, market orientation and organization learning strongly influences business performance. Innovation is an important function in management. Innovation is associated with company performance. Eris and Ozmen (2012) explain that market orientation and innovation are a strategy chosen by a company in achieving company performance. Company's role in viewing the

* Corresponding author

E-mail address: siti.fatonah@stie-aub.ac.id (S. Fatonah)

(C) 2022 Growing Science Ltd. All rights reserved.

doi: $10.5267 /$ j.uscm.2021.9.011 
importance of customers, competitors, and cross-functional coordination is the determining factor in creating innovation, leading to improved performance (Huhtala et al., 2013; Nupus \& Ichwanudin, 2021).

This research was conducted to measure SMEs' performance. The performance of SMEs in this study is influenced by market orientation, product innovation quality and competitive advantage. SMEs have many limitations in achieving superior performance (Lin et al., 2014), limited innovation through information technology (Dibrell et al., 2008), and weak resource capability (AlQershi et al., 2020). The importance of market orientation, product innovation quality and competitive advantage make SMEs able to survive in the ever-changing environment. The speed in responding to competitors, customers and product innovation quality make SMEs advantageous and able to improve their performance.

This research has some parts. First, literature review arrangement was focused more on the concept associated with market orientation, new product innovation, competitive advantage and SMEs' performance. Second, development of empirical research models and arrangements referring to previous studies were conducted thoroughly. Third, data analysis was conducted by arranging managerial implications and recommendations for future studies. In addition, this study specifically aims at testing the influence of market orientation on SMEs' performance through new product innovation and competitive advantage as relationship mediation. Besides, this study also directly tests the influence of market orientation on SMEs' performance.

\section{Literature Review and Hypotheses}

\subsection{Relationship of Market Orientation with Product Innovation}

Market orientation encourages companies to build business networking (Baker et al., 1999; Webb \& Krepapa, 2000). Furthermore, it is explained that market orientation positively influences company relationships with its business partners. It is important for companies to develop their networking, such as marketing of relationships to improve customer loyalty and lead to creation of innovation and performance. Organization capability effectively builds and maintains appropriate customer relationships after organization identifies and understands the needs of target customers through creation of innovation and networking of the company (Yadav et al., 2019; Riswanto, 2021). Meanwhile, the study conducted by Fang et al. (2014) finds that market orientation influences market performance and non-marketing performance (financial performance, innovation performance, and market performance). Thus, the following hypothesis is developed:

\section{$\mathbf{H}_{1}$ : Market orientation positively and significantly influences product innovation.}

\subsection{The Influences of Market Orientation and Competitive Advantage}

Market orientation is the company view of customer, competitor and inter-functional coordination in a company so as to be able to achieve competitive advantage and superior performance (Hinson et al., 2017; Yadav et al., 2019). Market oriented companies need to develop competitor strengths and weaknesses, use the knowledge to develop and implement strategies to create superior advantage and performance. The study conducted by Narver and Slater (1990) explains market orientation dimensions, including customer orientation and competitor orientation. For a company to apply the two orientations, it needs superior strategy and combining the third dimension, namely coordination between functions to improve company resistance to competitors as well as improve customer satisfaction (Nuryakin, 2018). Kohli and Jaworski (1990) study antecedent model and consequence of market orientation. The study result shows the role of senior manager policy, dynamics in interdepartmental cooperation in company, and organization system as antecedent of market orientation, followed with role of employee response, customer response, and company performance as the consequence of market orientation. Further, it is explained that a successful market orientation according to Kohli and Jaworski (1990) has 3 (main requirements, namely: focus on customer, coordinated marketing, and inter-department coordination in the company. Company must understand customer needs, so that company is able to apply orientation, either reactive or proactive orientation. Reactive orientation commonly makes companies concentrated on understanding and satisfying current consumer needs (Slater \& Narver, 1998). Thus, the following hypothesis is proposed:

\section{$\mathbf{H}_{2}$ : Market orientation positively, significantly influences competitive advantage.}

\subsection{Product Innovation and Market Performance}

Innovation is reflected in the use of information technology in company operational processes (Dibrell et al., 2008). Innovation also influences company competitiveness (Kiveu et al., 2019). Company capability to innovate may be viewed from its company business performance (Low et al., 2007). The significance influence of product innovation on business performance may be viewed from some previous researchers who test the concept of innovation in banking, company only, MSMEs, commercial company and logistic industry sectors such as in the studies conducted in previous research (Avlonitis \& Salavou, 2007; Eris et al., 2012; Deni et al., 2021; Han et al., 1998; Matear et al., 2002; Olavarrieta \& Friedmann, 2008). 
Another study also finds strong influence of product innovation on performance (Eshlaghy \& Maatofi, 2011). Innovation is needed by companies in response to environmental fluctuation and achieving comparative advantage and superior performance. The study conducted by Khin et al. (2010) finds that product innovation is an important determiner for companies in which through creation of innovative products, consumers obtain its benefit from the perspective of new features, design and function (Mughal, 2019). For a company to compete in the competitive market, the company does not only offer similar products or compete with price reasons only, but products of high quality must be created. Creation of high quality products is part of product innovation (Zhou, 2006). Thus, we propose the following hypothesis:

\section{H3: Product innovation positively, significantly influences market performance.}

\subsection{The Relationship of Competitive Advantage with SMEs' Performance}

The study conducted by Hult and Ketchen (2001) finds that a resource based view makes companies achieve a high degree of positional advantage, positively influencing business performance. Company expects the best market position, thus the market positional advantage influences improved business performance (Day \& Wensley, 1988; Srikarsem \& Ussahawanitchakit, 2010). Other researchers state there are two types of positioning advantage, namely achieving cheap cost and differentiation which influences business performance (Langerak, 2003). The study conducted by Baaij et al. (2004) tests the competitive advantage of companies entering the global market. The study results show that competitive advantage may be achieved through creation of innovation, improving superior business performance. Meanwhile, Clark and Machado (2006) in their study test exporter companies in creating competitive advantage based on technology advantage which increases business performance. Therefore, the following hypothesis is drawn up:

\section{H4: Competitive advantage positively influences market performance.}

\subsection{Market Uncertainty, Product Innovation and Market Performance}

Innovation strategy encourages creation of organization competitiveness and performance in a dynamic environment (Lin \& Chen, 2007). Meanwhile, the study conducted by Holtzman (2008) emphasizes the importance of organization growth and innovation in creating a company's future opportunities and success. The effort in achieving the company's long-term purpose, strategy focusing on innovation through collaboration is the main key to achieving business and performance sustainability (Gomes et al., 2009; Tanwari, 2020). Darroch and McNaughton (2002) explores the important role of innovation in achieving competitive advantage and dynamics of the business environment. Innovation is also viewed as a company strategy in achieving superior performance (Eris \& Ozmen, 2012). The study conducted by Singh and Garg (2008) explains that when a company is faced with various constraints related to resources, difficult innovation capability will be developed. Strategy in achieving competitiveness, companies need to have assets available, process and performance in creating the best product advantage in their industry. The dynamics of market and competition as the moderator effect in relationship between business strategy and competitive performance level are company focus in developing business strategy (Nandakumar et al., 2010; Wahyuni \& Praninta, 2021). Thus, the following hypothesis may be drawn up:

H5: Market uncertainty strengthens relationship between product innovation and market performance.

\subsection{Market Uncertainty, Competitive Advantage and Marketing Performance}

The study conducted by Verhees and Meulenberg (2005) explains company capability in market response full of competition dynamics is, among others, built by creating superior product, improving market intelligence so as to affect improved performance. Company also needs to achieve competitiveness and improved satisfaction of customer needs (Huang et al., 2019). Competitive advantage is the factor to drive achieving superior performance (Meutia \& Ismail, 2012; Arifiani et al., 2021). Achieving a high degree of competitive advantage, the performance achieved by the company improves. Rapid market and environmental change needs organization dynamic capability (Teece et al., 1997; Bukhori, 2021). Dynamic capability is deemed company capability in reconfiguring internal competence, integrating, building networking and responding to environmental change quickly.

\section{H6: Market uncertainty strengthens the relationship between competitive advantage and market performance.}

\section{Research Methods}

Quantitative approach was chosen to test the research hypotheses in this study. The data were collected through questionnaires distributed to batik SMEs owners or managements. The questionnaire was designed by developing instruments and indicators which reflect the variables of market orientation, product innovation, competitive advantage, market uncertainty and market performance of SMEs. The indicators measured were the reflective indicators of the variables. This study took samples of 171 Batik SME players in Surakarta City. Meanwhile, the analysis unit in this study was Batik SME owners or management. The samples were sampled using purposive sampling under consideration of experience and existence of Batik SMEs in 
operational and marketing process, number of employees and sales turnover of the product. Batik SMEs were chosen considering that until now Batik SMEs players grow in line with government support in developing Batik products as local wisdom. The data were collected by distributing questionnaires to the research samples. Based on previous studies and indepth literature review, some constructs were measured using items of question which reflected the research indicators. The indicators were measured using a five-point scale. The indicators were developed to operate the research variables for empirical tests. This research used quantitative design to test the hypotheses and empirical models. After literature review for identification of validity and reliability of measures in testing the five constructs, including market orientation, product innovation, competitive advantage, market uncertainty and market performance. The testing of the indicators of the five constructs has resulted in the instrument of validity and reliability and was tested with a five-point Likert scale (1 strongly disagree - 5 strongly agree).

\section{Results}

This study tested six research hypotheses. The hypotheses were tested using Structural Equation Modeling (SEM) in multivariate statistics program AMOS. The measurement model test was conducted in testing uni-dimensionality. The parameters that must be fulfilled in this test include viewing the value of Goodness of Fit (GoF). Measurement models in multivariate tests may be tested by viewing convergent validity. Further testing with SEM was conducted to test the parameters produced in goodness of fit and test on empirical research models explaining the causality relationship developed in this research. The result of a descriptive statistical test and correlation matrix explaining average value, standard deviation and relationship between constructs of market orientation, product innovation, competitive advantage, market uncertainty and market performance can be explained in Table 1.

Table 1

Correlation matrix, Mean and Standard Deviation

\begin{tabular}{|c|c|c|c|c|c|c|c|}
\hline Constructs & Mean & Std. Dev & 1 & 2 & 3 & 4 & 5 \\
\hline Market orientation & 3.026 & .604 & 1.000 & & & & \\
\hline Product innovation & 3.091 & .588 & $.565^{* *}$ & 1.000 & & & \\
\hline Competitive advantage & 3.273 & .546 & $.577 * *$ & $.563 * *$ & 1.000 & & \\
\hline Market uncertainty & 3.537 & .488 & $.583 * *$ & $.552 * *$ & $.535^{* *}$ & 1.000 & \\
\hline Marketing performance & 3.050 & .644 & $.518 * *$ & $.192 *$ & $.167 *$ & $.350 * *$ & 1.000 \\
\hline
\end{tabular}

This study used confirmatory factor analysis to analyze the validity and reliability of research instruments. Statistically, the result of the construct validity and reliability test, Variance Extract (VE), and Discriminant Validity (DV) may be explained in Table 2. Based on Table 2, the constructs of market orientation, product innovation, competitive advantage, market uncertainty and marketing performance meet the determined criteria, Validity Construct (VC) $>0.7$, Average Variance Extract $(\mathrm{AVE})>0.5$, and Discriminant Validity (DV) respectively higher than 0.7. The result of a test using the AMOS Program which explains the result. Table 2 explains the test on validity and reliability of constructs market orientation, product innovation, competitive advantage, market uncertainty and marketing performance. The result of validity and reliability test shows that each indicator of the five constructs meets the determined criteria, loading factor value $>0.6$. This conforms to the parameters developed by Hair et al. (1998) in testing construct validity and reliability.

Table 2

Validity and Reliability

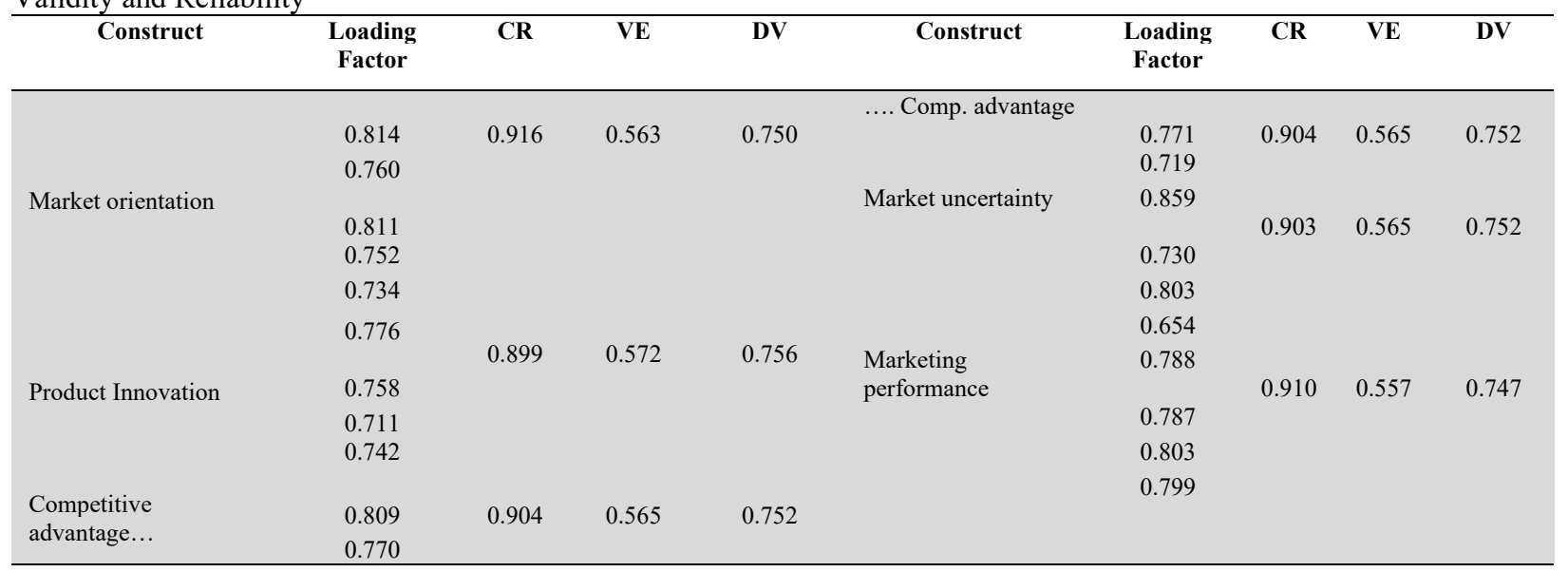

The confirmatory test on analysis factors and full model shows good results, that they have met the test criteria at assumption of goodness of fit of model. Meanwhile, the hypotheses in this study were proven using the assistance of Structural Equation 
Modeling (SEM) program. The result of statistical test with assistance of software AMOS shows the result of criteria cut off in goodness of fit has met the Chi-Square of 191.628, the result of probability value is 0.000 , CMIN/DF of 1.666 , TLI of 0.943, GFI value of 0.883 , AGFI value of 0.844 and RMSEA value of 0.063 indicating that the values conform to the determined cut-off. The value of standardized path coefficients testing the relationship between variables with the influence of market orientation, product innovation, competitive advantage and market performance is presented in the table below. Meanwhile, tests on the path analysis with respective hypotheses and test on moderation role in this research are shown in Table 3, consisting of 6 research hypotheses.

Table 3

Structural Model Analysis

\begin{tabular}{|c|c|c|c|c|c|}
\hline & Hypothesis & $\mathrm{CR}$ & $\beta$ & p-value & Result \\
\hline$\overline{\mathrm{H}_{1}}$ & Market orientation - product innovation & 7.977 & 0.668 & 0.000 & Supported \\
\hline $\mathrm{H}_{2}$ & Market orientation - competitive advantage & 8.032 & 0.551 & 0.000 & Supported \\
\hline $\mathrm{H}_{3}$ & Product innovation - marketing performance & 4.742 & 0.425 & 0.000 & Supported \\
\hline $\mathrm{H}_{4}$ & Competitive advantage - marketing performance & 4.234 & 0.430 & 0.000 & Supported \\
\hline $\mathrm{H}_{5}$ & Moderating 1: Market Uncertainty, Product Innovation and Market Performance & 11.549 & 0.664 & 0.000 & Supported \\
\hline $\mathrm{H}_{6}$ & Moderating 2: Market Uncertainty, Competitive Advantage and Marketing Performance & 12.395 & 0.690 & 0.000 & Supported \\
\hline
\end{tabular}

The result of the full model in testing the research hypothesis shows that the testing on $\mathrm{H} 1$ on the influence of market orientation on product innovation empirically proves the values of $\beta=0.668$, and $\operatorname{sig}=0.000<0.05$. Therefore, the hypothesis test shows the results that market orientation positively, significantly influences product innovation. H1 test is accepted. The testing on $\mathrm{H} 2$ testing the influence of market orientation on competitive advantage shows values of $\beta=0.551$, and sig $=0.000$ $<0.05$. Therefore, the hypothesis test shows the results that market orientation positively, significantly influences competitive advantage. $\mathrm{H} 2$ test is accepted. Statistical output on $\mathrm{H} 3$ testing the influence of product innovation on market performance shows values of $\beta=0.425$, and sig $=0.000<0.05$. Therefore, the hypothesis test shows the results that product innovation positively, significantly influences market performance. H3 test is accepted. Moreover, the analysis on $\mathrm{H} 4$ testing the influence of competitive advantage on market performance shows values of $\beta=0.430$, and sig $=0.000<0.05$. Therefore, the hypothesis test shows the results that competitive advantage positively, significantly influences market performance. The H4 test is accepted.

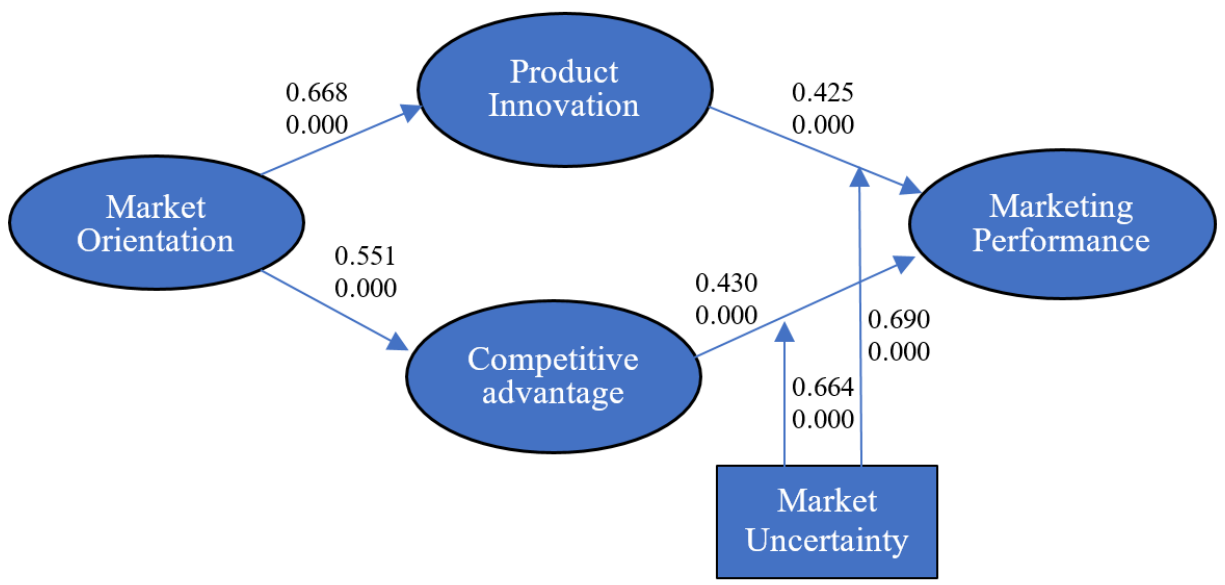

Fig. 1. Result of SEM analysis

The next analysis is to show the moderating effects. The result of test on moderation ole of market uncertainty in the relationship of product innovation with market performance and relationship of competitive advantage with market performance showed that on the testing on $\mathrm{H} 5$ to examine the moderation role of market uncertainty in the relationship of product innovation with market performance empirically shows values of $\beta=0.664$ with sig $=0.000<0.05$. Therefore, the hypothesis test shows the results that market uncertainty strengthens the relationship between product innovation and market performance. The H5 test is accepted. Furthermore, the empirical testing on H6 to examine the moderating effect of market uncertainty in the relationship of competitive advantage with market performance shows values of $\beta=0.690$, and sig $=0.000$ $<0.05$. Therefore, the hypothesis test shows the results that market uncertainty strengthens the relationship between competitive advantage and market performance. The H6 test is accepted.

\section{Discussion}

The research results show that market orientation positively, significantly influences product innovation. These study results conform to previous study that finds that market orientation positively influences achievement of innovation and performance 
(Baker et al., 1999; Webb \& Krepapa, 2000). This study finding also conforms to the result of previous study conducted by Fang et al. (2014) that market orientation influences market performance. Empirical evidence of the influence of market orientation on competitive advantage shows positive and significant results. This study result conforms to the finding of previous research explaining that market orientation is able to improve competitive advantage and superior performance (Hinson et al., 2017; Yadav et al., 2019). The study conducted by Narver and Slater (1990) also strengthens this study explaining that market orientation improves company resistance. Kohli and Jaworski (1990) also support this study result with finding that market orientation is able to achieve company competitiveness. The result of another hypothesis test also finds that product innovation positively, significantly influences market performance. This study result conforms to the finding of previous study that innovation influences company competitiveness (Kiveu et al., 2019; Mansyur, 2021). This study also conforms to other findings explaining that innovation influences business performance (Low et al., 2007). Another study also confirms this study finding, explaining that product innovation's influence on performance (Eshlaghy \& Maatofi, 2011). This study's finding supports the finding of previous study, explaining that positional advantage positively influences business performance (Hult \& Ketchen, 2001). Strong market position through market positional advantage influences improved business performance. This study finding also conforms to the finding that advantage influences business performance (Langerak, 2003). The study conducted by Baaij et al. (2004) also confirms this study finding on the positive influence of competitive advantage on performance. Clark and Machado (2006) also conforms to the finding of this research, explaining that competitive advantage improves business performance. Test on moderation role of market uncertainty that strengthens the relationship between product innovation and competitive advantage on market performance. This study result conforms to the finding of previous research, explaining that innovation encourages creation of competitiveness and performance in a dynamic environment (Lin \& Chen, 2007). Holtzman (2008) also supports the finding of this research that emphasizes the importance of innovation in creating a company's future opportunities and success. Darroch and McNaughton (2002) also conforms to this research finding, explaining that competitive advantage and dynamics of the business environment are important factors that companies need to pay attention to. The study conducted by Verhees and Meulenberg (2005) also supports this study finding, explaining that market response and dynamics of competition encourage companies to create superior products, improve market intelligence and affect improved performance. The result of another study also conforms to the finding of this research, that the effort to achieve competitiveness and improved satisfaction of customer needs are company's focus amidst market uncertainty (Huang et al., 2019). Competitive advantage is the factor to encourage achieving superior performance (Meutia \& Ismail, 2012).

\section{Conclusion}

The results of this research have contributed theoretically and practically. Theoretically, the results of this study have shown empirical proof of the influence of market orientation, product innovation and competitive advantage on market performance. In line with the results of this study, theoretically the results of this study have contributed to the body knowledge of resources-based view, a theory explaining company internal capability as superior resource to achieve competitive advantage and performance. The results of this study also prove the findings of previous studies indicating that market orientation is an important strategy in achieving the degree of product innovation and competitiveness of a company in improving performance and is part of growth strategy in response to rapidly changing market dynamics. The practical implication of the result of this study also shows that it is important for Batik SMEs players and owners in Surakarta in improving their market performance. In addition, the findings of this research also show the mediation role of product innovation and competitive advantage as a bridge to connect the role of market orientation in market performance. The interesting finding in this study proves that market uncertainty strengthens the relationship of product innovation and competitive advantage on market performance. This indicates that an uncertain market condition encourages Batik SMEs players to develop their product innovation and competitive advantage in order to achieve superior market performance.

\section{References}

AlQershi, N. A., Mokhtar, S. S. M., \& Abas, Z. B. (2020). CRM dimensions and performance of SMEs in Yemen: the moderating role of human capital. Journal of Intellectual Capital, ahead-of-print(ahead-of-print). doi: 10.1108/jic-052020-0175

Arifiani, L., Prabowo, H., Furinto, A., \& Kosasih, W. (2021). Driving growth performance shaped by environmental uncertainty and integrative strategy: The supply chain analysis of business transformation in ict companies. Uncertain Supply Chain Management, 9(4), 995-1004.

Avlonitis, G. J., \& Salavou, H. E. (2007). Entrepreneurial orientation of SMEs, product innovativeness, and performance. Journal of Business Research, 60(5), 566-575. doi: 10.1016/j.jbusres.2007.01.001

Baaij, M., Greeven, M., \& Dalen, J. V. (2004). Persistent Superior Economic Performance, Sustainable Competitive Advantage, and Schumpeterian Innovation: Leading Established Computer Firms, 1954-2000. European Management Journal, 22(5), 517-531.

Baker, T. L., Simpson, P. M., \& Siguaw, J. A. (1999). The Impact of Suplier' Perceptions of Reseler Market Orientation on Key relationship Constructs. Journal of the Academy of Marketing Science, 27(1), 50-57.

Bharadwaj, S. G., Varadarajan, P. R., \& Fahy, J. (1993). Sustainable competitive advantage in service industries A Conceptual Model and Research Proposition. Journal of Marketing, 57(4), 83. 
Bukhori, A. (2021). The Role of Youth in Managing Educational Startup: Case Study of PrivatQ Startup. Research Horizon, $1(2), 62-70$.

Clark, R., \& Machado, M. (2006). Does Information Technology Provide Competitive Advantage and Improve Performance? An Empirical Study of Trading Companies in Brazil. Brazilian Business Review, 3(2), 175-199.

Darroch, J., \& McNaughton, R. (2002). Eamining the Link Between Knowledge Management Practices and Types of Innovation. Journal of Intellectual Capital, 3(3), 210-222.

Day, G. S., \& Wensley, R. (1988). Assessing Advantage: A Framework for Diagnosing Competitive Superiority. Journal of Marketing, 52(April), 1-20. doi: 10.2307/1251261

Deni, A., Riswandi, R., Sobar A., Hamidi, D. Z., \& Permadi, I. (2021). The effect of product turnover on company performance of SMEs. Research Horizon, 1(3).

Dibrell, C., Davis, P. S., \& Craig, J. (2008). Fueling Innovation through Information Technology in SMEs. Journal of Small Business Management, 46, 203.

Eris, E. D., \& Ozmen, O. N. T. (2012). The Effect of Market Orientation, Learning Orientation and Innovativeness. International Journal of Economic Sciences and Applied Research, 5(1), 77-108.

Eris, E. D., Neczan, O., \& Ozmen, T. (2012). The effect of market orientation, learning orientation and innovativeness on firm performance: A research from turkish logistics sector. International Journal of Economic Sciences and Applied Research, 5(1), 77-108.

Eshlaghy, A. T., \& Maatofi, A. (2011). Learning Orientation, Innovation and Performance. European Journal of Social Sciences, 19(1).

Fang, S.-R., Chang, E., Ou, C.-C., \& Chou, C.-H. (2014). Internal market orientation, market capabilities and learning orientation. European Journal of Marketing, 48(1/2), 170-192.

Gomes, C. F., Yasin, M. M., \& Lisboa, J. O. V. (2009). Benchmarking competitive methods and strategic choices of Portuguese SMEs. Benchmarking: An International Journal of Agribusiness in Developing and Emerging Economies, 16(6), 729-740. doi: 10.1108/14635770911000079

Hair, J. F., Anderson, R. E., R.L Tatham, \& C, B. W. (1998). Multivariat Date Analysis. Prentice Hall Inc, Upper Saddle River.

Han, J. K., Kim, N., \& Srivastava, R. K. (1998). Market orientation and organizational performance: Is innovation a missing link? Journal of Marketing, 62(4), 30-45.

Hinson, R. E., Abdul-Hamid, I. K., \& Osabutey, E. L. C. (2017). Investigating market orientation and positioning in starrated hotels in Ghana. International Journal of Contemporary Hospitality Management, 29(10), 2629-2646.

Holtzman, Y. (2008). Innovation in research and development tool of strategic growth. Journal of Management Development, 27(10), 1037-1052. doi: 10.1108/02621710810916295

Hsu, Y. (2012). Linking Design, Marketing, and Innovation Managing the Connection for Competitive Advantage. International Journal of Business Research and Management (IJBRM), 3(6).

Huang, Z., Liao, G., \& Li, Z. (2019). Loaning scale and government subsidy for promoting green innovation. Technological Forecasting and Social Change, 144, 148-156. doi: 10.1016/j.techfore.2019.04.023

Huhtala, J.-P., Sihvonen, A., Frosen, J., \& Tikkanen, M. J. a. H. (2013). Market orientation, innovation capability and business performance: Insights from the global financial crisis. Baltic Journal of Management, 9(2), 134-152. doi: 10.1108/BJM-03-2013-0044

Hult, G. T. M., \& Ketchen, D. J. (2001). Does Market Orientation Matter?: A Test of the Relationship between Positional Advantage and Performance. Strategic Management Journal, $22(9$ (sep)), 899-906.

Khin, S., Ahmad, N. H., \& Ramayah, T. (2010). Product innovation among ICT technopreneurs in Malaysia. Business Strategy Series, 11(6), 397-406.

Kiveu, M. N., Namusonge, M., \& Muathe, S. (2019). Effect of innovation on firm competitiveness: the case of manufacturing SMEs in Nairobi County, Kenya. International Journal of Business Innovation and Research, 18(3), 307-327.

Kohli, \& J. Jaworski. (1990). Market-orientation: The construct, research propositions, and managerial implications. Journal of Marketing, 54, 1-18.

Kropp, F., Lindsay, N. J., \& Shoham, A. (2006). Entrepreneurial, market, and learning orientations and international entrepreneurial business venture performance in South African firms. International Marketing Review, 23(5), 504-523. doi: $10.1108 / 02651330610703427$

Langerak, F. (2003). The Effect of Market Orientation on Positional Advantage and Organizational Performance. Journal of Strategic Marketing, 11(June), 93-115.

Lertpachin, C., Wingwon, B., \& Noithonglek, T. (2013). The effect of marketing focus, innovation and learning organization on the building of competitive advantages: empirical evidence from ISO 9000 certified companies. Journal of Strategic Marketing, p. 1 - 8. doi: 10.1080/0965254X.2013.790469

Lin, C. Y.-Y., \& Chen, M. Y.-C. (2007). Does innovation lead to performance An empirical study of SMEs in Taiwan. Management Research News, 30(2), 115-132. doi: 10.1108/01409170710722955

Lin, H., Zeng, S. X., Ma, H. Y., Qi, G. Y., \& Tam, V. W. Y. (2014). Can political capital drive corporate green innovation? Lessons from China. Journal of Cleaner Production, 64, 63-72. doi: 10.1016/j.jclepro.2013.07.046

Low, D. R., Chapman, R. L., \& Sloan, T. R. (2007). Inter-relationship between innovation and market orientation in SMEs. Management Research News, 30(12), 878-891.

Mansyur, M. (2021). Marketing Opportunities for Bank Syariah Mandiri e-Banking Services as a Payment Method. Research 
Horizon, 1(2), 71-80.

Matear, S., Osborn, P., Garrett, T., \& Gray, B. J. (2002). How does market orientation contribute to service firm? An examination of alternative mekanism. European Journal of Marketing, 36(9/10), 1058-1075.

Meutia, \& Ismail, T. (2012). The Development of Entrepreneurial Social Competence and Business Network to Improve Competitive Advantage and Business Performance of Small Medium Sized Enterprises: A Case Study of Batik Industry in Indonesia. Procedia - Social and Behavioral Sciences, 65, 46-51. doi: 10.1016/j.sbspro.2012.11.089

Mughal, M. (2019). Impact of green supply chain management practices on performance of manufacturing companies in Jordan: A moderating role of supply chain traceability. Arthatama, 3(2), 67-82.

Munck, J. C., Tkotz, A., Heidenreich, S., \& Wald, A. (2020). The performance effects of management control instruments in different stages of new product development. Journal of Accounting \& Organizational Change, 16(2), 259-284.

Nandakumar, M. K., Ghobadian, A., \& O'Regan, N. (2010). Business-level strategy and performance The moderating effects of environment and structure. Management Decision, 48(6), 907-939. doi: 10.1108/00251741011053460

Narver, J. C., \& Slater, S. F. (1990). The effect of a market orientation on business profitability. Journal of Marketing, 54(4), 20-35.

Nupus, H., \& Ichwanudin, W. (2021). Business Network Accessibility, Customer Relationship Management and Shared Value Creation on Family Business Performance. Research Horizon, 1(4).

Nuryakin. (2018). Competitive Advantage and Product Innovation: Key Success of Batik Smes Marketing Performance In Indonesia. Academy of Strategic Management Journal, 17(2), 1-17.

Olavarrieta, S., \& Friedmann, R. (2008). Market orientation, knowledge-related resources and firm performance. Journal of Business Research, 61(6), 623-630.

Priagung Hutomo, P.T., \& Pudjiarti, E.S. (2021). Supply chain assessment of the organizational learning and market uncertainty on corporate performance of small scale steel industry in Indonesia. Uncertain Supply Chain Management, $9(1), 39-48$.

Riswanto, A. (2021). Competitive Intensity, Innovation Capability and Dynamic Marketing Capabilities. Research Horizon, $1(1), 7-15$.

Simpson, M. (2004). Competitive Advantage in SMEs Organising for Innovation and Change. Journal of Small Business and Enterprise Development, 11, 263 - 269.

Singh, R. K., \& Garg, S. K. (2008). Strategy development by SMEs for competitiveness : a review. Benchmarking: An International

Slater, S. F., \& Narver, J. C. (1998). Customer-led and market oriented: Let's not confuse the two. Strategic Management Journal, 19(10), 1001-1006.

Srikarsem, U., \& Ussahawanitchakit, P. (2010). Management Audit Effectiveness and Organizational Survival of Thai-Listed Firms: Mediating Role of Value Added Performance, Govermance Outcome and Outperforming Market Position. International Journal of Business Research, 10(5), 1-25.

Tanwari, A. (2020). A Study on Assessing the Relationship between Green Marketing and Brand Loyalty in Manufacturing Sector of Greece: A Moderating Role of Green Supply Chain Practices. Arthatama, 4(1), 44-55.

Teece, D. J., Pisano, G., \& Shuen, A. (1997). Dynamic capabilities and strategic management. Strategic Management Journal, 18(7).

Verhees, F. J. H. M., \& Meulenberg, M. T. G. (2005). Market Orientation, Innovativenes, Product Innovation, and Performance in Small Firms. Journal of Small Business Management, 42(2), 134-154.

Wahyuni, S., \& Praninta, A. . (2021). The Influence of Brand Equity and Service Quality on Purchase Decisions on Garuda Indonesia Airline Services. Research Horizon, 1(1), 28-38.

Webb, D. W., \& Krepapa, A. (2000). An Exploration of The Meaning and Outcomes of a Customer-Defined Market Orientation. Journal of Business Reseaerch, 48, 101-112.

Yadav, S. K., Tripathi, V., \& Goel, G. (2019). Mediating effect of innovation with market orientation and performance relationship. Management Research: Journal of the Iberoamerican Academy of Management. doi: 10.1108/mrjiam-032018-0827

Yu, W., Ramanathan, R., \& Xingyu Wang, J. Y. (2018). Operations capability, productivity and business performance: The moderating effect of environmental dynamism. Industrial Management \& Data Systems, 118(1), 126-143.

Zhou, K. Z. (2006). Innovation, imitation, and new product performance: The case of China. Industrial Marketing Management, 35(3), 394-402.

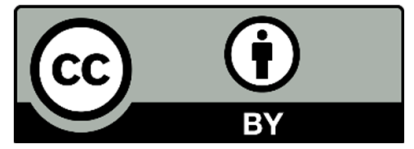

(C) 2022 by the authors; licensee Growing Science, Canada. This is an open access article distributed under the terms and conditions of the Creative Commons Attribution (CCBY) license (http://creativecommons.org/licenses/by/4.0/). 